\title{
Notes
}

\section{THE IDENTITY CRISIS IN PUBLIC INTEREST LAW}

\author{
DAVID R. ESQUIVEL
}

Who shall speak for the people?

Who has the answers?

Where is the sure interpreter?

Who knows what to say? ${ }^{1}$

\section{INTRODUCTION}

Public interest law is in a state of crisis. ${ }^{2}$ The number of poor people in the United States has continued to rise over the last two decades while the number of lawyers for the poor has declined by approximately one-third since $1990 .^{3}$ Law schools are not preparing students to enter into public interest law careers and are actually dissuading many law students froin realizing a goal of full-time einployment in public interest law after graduation. ${ }^{4}$ In the 1988 graduating class of law students, the national average for placeinent into public interest law jobs was only $3 \% .^{5}$ Meanwhile, the

1. CARL Sandburg, The People, Yes (1936), quoted in Glendon Schubert, THE PUBLIC INTEREST 7 (1960).

2. See Luke Cole, The Crisis and Opportunity in Public Interest Law: A Challenge to Law Students to be Rebellious Lawyers in the '90s, 4 B.U. PUB. INT. L.J. 1 (1994); Debra S. Katz \& Lynne Bernabei, Practicing Public Interest Law in a Private Public Interest Law Firm: The Ideal Setting to Challenge the Power, 96 W. VA. L. REv. 293, 300 \& nn.24-26 (1993) ("[I]n 1977, one commentator estimated that public interest lawyers who work for nonprofit, tax-exempt groups consitute[d] only one thousandth of 1 percent of the legal profession. It is our belief that this percentage . . . is less today.").

3. See Cole, supra note 2, at 2; see also Randall Samborn, ABA Study: Legal Needs Not Met, NAT'L L.J., Feb. 14, 1994, at 3.

4. See Robert V. Stover, Making It and BReaking It: ThE fate of PUblic INTEREST COMMTTMENT DURING LAW SCHOOL (Howard S. Erlanger ed., 1989).

5. See Jason BOURKE, PUblic LOSS: AN EXAMINATION OF tHE "REORganizaTION" OF PUBLIC INTEREST LAW CAREeR SERVICES AT HARVARD LAW SCHOOL 1 (1989) (citing the Employment Report and Salary Survey of the Class of 1988, performed by the National Association for Law Placement). 
American Bar Association has estimated that more than $93 \%$ of the legal problems of the poor go unserved each year. ${ }^{6}$

There is a crisis in public interest law, and it is more than a statistical one. Public interest law also suffers from an identity crisis-a crisis of what public interest law is and where it is goimg. Luke Cole, a staff attorney with the California Rural Legal Assistance Foundation, notes that while poor people's lawyers in the 1960s were "visionaries," many of today's advocates for the poor choose a "path of least resistance" by involving theinselves in cases that rarely address the systemic causes of poverty. ${ }^{7}$ According to Cole, poverty lawyers inust rededicate theinselves to a specific vision for poverty law-helping poor people move up and out of poverty. ${ }^{8}$ The first director of the Legal Services Program, Clinton Bamberger, embraced the goal of inoving poor people froin deprivation, depression, and despair to opportunity, hope, and ambition." "Somewhere along the line," Cole says, "we've lost that vision."10 This statement, however, signals more than a change in vision. Poverty law, and more generally public niterest law, no longer appears to have any vision at all. Instead, modern public interest law rehes on a procedural identity to justify what it seeks to do.

The rhetoric underlying public interest law is that of representation." "Representation of the unrepresented and underrepresented" is often cited by the public interest law community as the defining characteristic of its diverse practices; thus, public interest law is defined in procedural ternis. ${ }^{12}$ Representation imvolves the defense of another's interests; representation does not indicate an endorsement of the good that would result from achieving the substantive goals for which the representation was

6. See id. (citing Brooksley Born, Serving the Poor, A.B.A. J., Mar. 1, 1988, at 144).

7. Cole, supra note 2 , at 2 .

8. See id. at 9-10.

9. See id. at 10 (citing HARRY P. STUMPF, COMMUNTTY POLITICS AND LEGAL SERVICES: THE OTHER SIDE OF THE LAW 143 (1975)).

10. Id.

11. It is, of course, impossible to use broad generalizations that would accurately describe all of modem public interest law. Public interest law is an extremely diverse field for which there can be no single justification or rhetoric that all of its adherents and practitioners would espouse. It is lioped, however, that the statements and observations from the public interest literature which are found in this Note will resonate and comport with the reader's understanding of mucls of today's public interest law rhetoric.

12. For examples of the breadth of organizations which are considered "public interest law" groups, see infra text accompanying notes 67-72. 
begun. When the public interest law community defines itself procedurally, it implies that "[a]dvancement of the public interest does not necessarily depend upon substantive victories of the unrepresented but instead [upon] participation."13

A procedural conception of justice seems to be, at first, a logical atteinpt to provide an identity for an otherwise diverse field:

When supporters of public interest law justify their efforts in [procedural] terms, they need not identify with the substance of the claims inade by the formerly unrepresented; instead, they can argue that some concept of procedural justice requires that the unrepresented have an opportunity to present their position forcefully to decisionmakers. ${ }^{14}$

This notion of justice is a liberal ${ }^{15}$ conception, articulated by those who believe that the right should be prior to the good, that following the rules should be valued higher than what those rules seek to achieve. ${ }^{16}$ The priority of the right over the good is made concrete in public interest law's rhetoric of representation, which eschews reliance on the substantive good of underlying claims. It is this procedural vision of justice that has created the crisis of identity in public interest law today.

This Note argues that procedure-based conceptions of justice fail to provide an adequate framework for public interest law because the pursuit of a substantively better society is an essential component of any moveinent for legal reform or enforcement of pre-existing rights. ${ }^{17}$ Part I examines the work of contemporary liberal philosopher John Rawls in Political Liberalism..$^{18}$ Relying on the conception of "justice as fairness" developed in Rawls' $A$

13. Benjamin W. Heineman, Jr., In Pursuit of the Public Interest, 84 YALE L.J. 182, 184 (1974) (book review).

14. Id.

15. For purposes of this Note, "liberal" and "liberalism" should be understood as a reference to Enlightenment political and philosophical thought. See MICHAEL J. SANDEL, LIBERALISM AND THE LIMTSS OF JUSTICE 1 (1982).

16. See infra Part I.

17. This Note will continue to use the phrases "public interest" and "public interest law," despite the arguments made throughout the Note that the "public interest" cannot adequately nor accurately provide a theoretical framework for the work done by "public interest lawyers." "Despite the slipperiness of the term 'the public interest,' its popularity inakes its use inconvenient to avoid." Comment, The New Public Interest Lawyers, 79 YALE L.J. 1069, 1071 n.3 (1970).

18. JOHN RAWLS, POLTTICAL LIBERALISM (1993). 
Theory of Justice, ${ }^{19}$ Political Liberalism explains the procedural view of justice essential to public interest law's current identity. The Note then examines aspects of public interest law as seen through a Rawlsian conception of justice and argues that this conception of justice is unable to accurately and adequately define the work of public interest lawyers.

Part II traces the roots of public interest law by describing two of modern public interest law's predecessors: the anti-war activities of the National Civil Liberties Board (later to becone the American Civil Liberties Union) and the civil rights achievements of the Reverend Martin Luther King, Jr. and the Southern Christian Leadership Conference. Part II observes that modern public interest law connes froni a tradition that espoused a substantive vision of the good and argues that the incongruity between these substantive visions of justice and modern public imterest law's reliance on procedural justice fuels public interest law's current crisis of identity.

Part III examines the rise of pro-free enterprise public interest organizations in the late 1970s in response to the successes of "traditional" public interest groups. Under a procedural conception of justice, the pro-free enterprise organizations' claim to the "public interest" should pose no theoretical problenis. Part III observes, however, that the pro-free enterprise organizations have not been well received by the traditional public interest community, revealing an inaccuracy and inadequacy in that community's procedural conception of its role. Part IV concludes that procedure-based theoretical justifications are inerely an "uncontroversial gloss" for substantive values and that it is impossible to remove a substantive account of the good froni public interest law without sacrificing the ability of its lawyers to do anything at all.

\section{RaWlsian LIBERALISM AND PRocedURAL JUSTICE}

A Theory of Justice, published by Harvard professor John Rawls in 1971, provided a liberal conception of justice in a theory known as "justice as fairness." 20 Justice as fairness is essentially an account of how nembers of a diverse, plurahistic society "decide once and for all what is to count among them as just and

19. JOHN RAWLS, A THEORY OF JUSTICE (1971).

20. Id. at 3-53. 
unjust." ${ }^{321}$ Rawls' theory of justice as fairness has become one of the inost important works in pohitical philosophy in the past century and has "changed the framework for scholarly debate about what constitutes a fair, just society."22 In Political Liberalism, published in 1993, Rawls refined and elaborated his theory. ${ }^{23}$

Rawls' theory begins with the assumption that the inodern democratic society is endlessly diverse, not merely by happenstance, but as the inevitable result of democratic process: "[T] diversity of reasonable comprehensive rehigious, philosophical, and moral doctrines found in modern democratic societies is not a mere historical condition that may soon pass away; it is a permanent feature of the public culture of democracy."24 Rawls argues that the individual citizen is the building block for the liberal democracy. This individual makes decisions and expresses preferences about competing rehigious, philosophical, and inoral doctrimes, subject to no one's authority. ${ }^{25}$ Because each individual in a democratic society will espouse different views about what really matters, and because each individual is considered equal, democratic society must find a way to ensure that, quite simply, everyone can just get along.

21. Id. at 12 .

22. Symposium on Political Liberalism, 94 CoLUM. L. REv. 1813, 1813 (1994); see also Lawrence B. Solum, Situating Political Liberalism, 69 CHI.-KENT L. REV. 549, 549-51, 550 n.6 (1994) (describing $A$ Theory of Justice as a modern classic with a profound impact on contemporary thinking).

23. A number of commentators have indicated several ways in which Political Liberalism differs from Rawis' earlier work in A Theory of Justice. See, e.g., Michael J. Sandel, Political Liberalism, 107 HARV. L. REv. 1765 (1994) (book review); Heidi M. Hurd, The Levitation of Liberalism, 105 YALE L.J. 795, 803-05 (1995) (book review) (citing critiques of Political Liberalism). However, this Note uses Political Liberalism as Rawls' articulation of procedural justice, because it is his latest work in this area and because Rawls himself considers it an extension of his argument in $A$ Theory of Justice. See RAWLS, supra note 19, at xv-xvi. For purposes of this Note, any philosophical changes between Rawls' previous work and Political Liberalism are unimportant. Rawls' central project, the attempt to define justice in a pluralistic society along strictly procedural lines, remains the same.

24. RAWLS, supra note 18 , at 36 .

25. The philosopher Alasdair MacIntyre, a critic of modern liberalism, describes this idea as the rise of emotivism. MacIntyre argues that liberalism has created a society in which moral thought is only the expression of individual preferences and desires. See ALASDAIR MACINTYRE, AFTER VIRTUE: A STUDY IN MORAL THEORY 6-22 (2d ed. 1984). At least one commentator has observed that Political Liberalism not only ignores Professor MacIntyre's critique, but "does not even acknowledge the existence of any counter-enlightenment tradition in Western political thought." Paul F. Campos, Secular Fundamentalism, 94 COLUM. L. REV. 1814, 1816 (1994). 
Since there is no comprehensive doctrine affirmed by all citizens, Rawls posits the idea that all reasonable religious, philosophical, and moral doctrines must have some common ground in the "domain of the political." According to Rawls, each individual in society lias a bifurcated vision of the good: one vision stems from the dogma of the individual's chosen reasonable comprehensive doctrine; the other comports with a "publicly recognized political conception of justice."27 Rawls calls the latter, public conception of justice the "overlapping consensus." 28 This is the consensus formed when all individuals endorse one political conception of justice without sacrificing their own individual comprehensive doctrines. "Social unity is based on a consensus on the pohitical conception; and stability is possible when ... the requirements of justice are not too mucls in conflict with citizens' essential interests as formed and encouraged by their social arrangeinents. ${ }^{330}$

In attempting to achieve this overlapping consensus, Rawls inaintains that individuals should not rely on arguments based on their own religious, philosophical, or moral doctrines, but should embrace a language of "public reason" acceptable to every individual, regardless of their own personal comprehensive beliefs. This reliance upon a "public reason" requires that, in matters of basic justice,

we are not to appeal to comprehensive religious and philosophical doctrines-to what we as individuals or nembers of associations see as the whole truth.... As far as possible, the knowledge and ways of reasoning that ground our affirming the principles of justice ... are to rest on the plain truths now widely accepted, or available, to citizens generally. ${ }^{31}$

Justice, then, is the product of this process, whereby citizens achieve an "overlapping consensus" by engaging in dialogue using the language and tenets of public reason.

Rawls points out, liowever, that the notion of overlapping consensus is not "consensus" as that term is used in everyday

\footnotetext{
26. RAWLs, supra note 18 , at 38 .

27. Id.

28. Id. at 39.

29. See id. at $39-40$.

30. Id. at 134 .

31. Id. at 224-25.
} 
politics to mean compromise. The overlapping consensus does not strike a balance between conflicting reasonable comprehensive doctrines. ${ }^{32}$ The overlapping consensus is freestanding, ${ }^{33}$ it is not dependent on the dogma of any particular reasonable comprehensive doctrine. It is a conception of justice "that may be shared by citizens as a basis of a reasoned, informed, and willing political agreement. It expresses their shared and public political reason. . . . [It] should be, as far as possible, independent of the opposing and conflicting philosophical and religious doctrines that citizens affirm." ${ }^{\text {"34 }}$ Because the overlapping consensus is freestanding, it does not rely on any single substantive account of the good. Instead, it is the confluence of all reasonable comprehensive religious, philosophical, and moral beliefs that are expressed using the language of public reason.

The principle most important for Rawls' theory of justice and for this Note's discussion-the priority of the right over the good-requires that the substantive vision of the good that is embodied in comprehensive religious, moral, and philosophical doctrines not take precedence over the overlapping consensus, the procedure whereby justice is articulated using the language of public reason.

$[P]$ ure procedural justice obtains when there is no independent criterion for the right result: instead there is a correct or fair procedure such that the outcome is likewise correct or fair, whatever it is, provided that the procedure has been properly followed. ${ }^{35}$

"Justice as fairness" means that procedure, the exercise of achieving the overlapping consensus through a dialogue in the language of public reason, must exist prior to any compreliensive view of the good. ${ }^{36}$ Rawls writes that the priority of the right "means that admissible ideas of the good must respect the limits of, and serve a role within, the political conception of justice."37 Thus, Rawls'

32. See id. at 39.

33. See id. at 12-13.

34. Id. at 9 (emphasis added).

35. RAWLS, supra note 19 , at 86 (emphasis added).

36. For an exposition of Rawls' priority of the right over the good in $A$ Theory of Justice, see SANDEL, supra note 15 , at 165-68.

37. RAWLS, supra note 18, at 176. Rawls adds: "The particular meaning of the priority of right is that comprehensive conceptions of the good are admissible, or can be pur- 
theory of "justice as fairness" is a purely procedural conception of justice.

As an example, imagine the way that two very different citizens, a Muslim and a Christian, develop a mutually acceptable, public determination of what is just in a particular situation. Both the Muslim and the Christian should agree, under Rawls' assumption, that only the individual can decide what religious beliefs she will hold, and that the state should not impose any particular compreliensive doctrine, such as religious faith, on anyone. Despite their different theological beliefs, Rawls envisions that both the Muslim and the Christian will leave "doginatic" vocabulary aside and embrace a "public language" common to both. The two might agree, for instance, that children in this country should not go hungry. Both Muslim and Christian could agree to this understanding of basic justice without reference to their own comprehensive doctrines. Using the language of public reason, they might agree that healthy, well-fed children are more productive in school. Using the language of public reason, they might also agree that healthy children who do well in school will likely go on to productive employment which will benefit the national economy and reduce the number of citizens who rely on government entitlements. Aside from these rationales, they might simply agree that children have a right to be free from hunger. Without relying on any comprehensive rehgious, philosophical, or moral doctrines, both Muslim and Christian might agree that children in this country should not go liungry as a matter of justice.

The Muslim, in her "comprehensive" sense of justice, may believe that children should not go hungry because of a vision of justice set forth in the Koran, and the Christian may be led to the same belief because of Christ's divinity and teaclimgs in the Sermon on the Mount, but, under Rawls' theory, this sectarian language should not be used for the public purpose of achieving the overlapping consensus. For the Muslim and the Christian, their deeply-held religious beliefs are not acceptable in the discourse of public reason; their religious beliefs only serve to buttress what is a freestanding conception of justice, articulated using a public vocabulary common to both. These citizens, then, would support a government program for feeding liungry children not because such

sued in society, only if their pursuit conforms to the political conception of justice . . .." Id. at $176 \mathrm{n} .2$ (emphasis added). 
programs helped fulfill the substantive tenets of their faiths, but rather because the decision came as the result of the operation of a fair process. This illustrates the priority of the right over the good. The problem, which will be illustrated later in the discussion of public interest law, is whether anyone actually thinks or behaves in this way or would even choose to do so.

In Political Liberalism, Rawls uses "the troubled question of abortion" to illustrate his theory of how an overlapping consensus may be achieved without rehance on comprehensive doctrines. ${ }^{38}$ Rawls supposes that the abortion debate centers on three important pohtical values: due respect for human life, the ordered reproduction of political society over time, and the equality of women as citizens..$^{39}$ Rawls concludes that any "reasonable balance" of these three factors would provide a woman with a "duly qualified right to decide whether or not to end her pregnancy during the first trimester," $" 40$ and that "any comprehensive doctrine that leads to a balance of political values excluding that duly qualified riglit in the first trimester is to that extent unreasonable." ${ }^{\text {"41 }}$ Rawls' illustration, which on its face dismisses the Republican Party's abortion platform in the 1996 election $^{42}$ as "unreasonable," seems problematic as an atteinpt to define a vision of justice to which all could agree.

This discussion of practical applications of Rawls' theory introduces the problems posed by procedural justice as a theoretical foundation for the practice of public interest law. For Rawls, the best hope for justice in our diverse culture is a common agreement to obey certam procedures. Justice, then, is what results from fair operation of the process. It is this procedural conception of justice that has contributed to the identity crisis in public interest law by taking away the ability of lawyers for the poor and marginalized to articulate and work towards a substantive vision of a better society.

38. See RAWLS, supra note 18 , at $243-44$ n.32.

39. See id. at 243 n.32.

40. Id.

41. Id. (emphasis added).

42. See Steven V. Roberts, Whose Party is This? The Battle of San Diego, U.S. NEWS \& WORLD REP., Aug. 19, 1996, at 39; Robert Shogan, Abortion Foes Shred Dole's Tolerance Clause, L.A. TMME, Aug. 6, 1996, at 1. 


\section{Public Interest Law'S Predecessor Groups}

\section{A. The ACLU and the Civil Rights Movement}

Although lawyers have long regarded service to the community as a professional obhigation, ${ }^{43}$ the phenomenon of the "public interest lawyer" is relatively recent. The term "public interest law" lias only been in use for twenty-five to thirty years. ${ }^{44}$ This is not to say, however, that public interest law spontaneously appeared in the late 1960s. Today's public interest law traces its origins through several legal movements of the last century. Two of these efforts were the National Civil Liberties Bureau (predecessor to today's American Civil Liberties Union (ACLU)) and the civil rights campaign of the Southern Christian Leadership Conference (SCLC) and the Reverend Martin Luther King, Jr. These two movements sought to represent particular constituencies with the purpose of improving those groups' place in society. The niovements represented chents because of the importance of their substantive claims, demonstrating that noodern public interest law einanates from groups grounded in substantive expressions of the good.

In 1917, Roger Baldwin left his job in the Midwest to donate his time to an organization in New York, the American Union Agamst Militarism (AUAM), that opposed United States preparations to enter World War I. ${ }^{45}$ Within the AUAM, Baldwin created the Bureau for Conscientious Objectors to "protect the rights of people to speak out and oppose the war as their consciences dictated." ${ }^{46}$ After internal struggles at the AUAM, the Bureau for Conscientious Objectors changed its name and became an independent organization, the National Civil Liberties Bureau. According to his biographer, Baldwin and his commitment to protecting conscientious objectors defined the organization. "What

43. See Model Rules of Professional Conduct Rule 6.1 (1995).

44. Commentators unanimously agree that the public interest law phenomenon began between 1965 and 1970. See NAN ARON, LIBERTY AND JUSTICE FOR ALL 6 (1989); COUNCIL FOR PUBLIC INTEREST LAW, BALANCINO THE SCALES OF JUSTICE: FINANCINO PUBLIC INTEREST LAW IN AMERICA 19 (1976) [hereinafter BALANCINO THE SCALES]; Katz \& Bernabei, supra note 2, at 297; Nicole T. Chapin, Note, Regulation of Public Interest Law Firms by the IRS and the Bar: Making It Hard to Serve the Public Good, 7 GEO. J. LEGAL ETHICS 437, 441 (1993).

45. PEgGY LAMSON, ROger BALDWIN: FOUNDER OF THE AMERICAN CIVIL LIBERTIES UNION 66-69 (1976).

46. Id. at 69. 
[Roger Baldwin] brought to the Civil Liberties Bureau, which he had created, was a driving leadership based on his own deeply felt belief in the rightness of his cause." ${ }^{47}$ Baldwin himself commented: "I was doing what my deepest convictions demanded and working with people who shared them." 48

Baldwin worked diligently in defense of pacifists and conscientious objectors at least in part because of his own "extreme" pacifist position. ${ }^{49}$ Because of his opposition to war, Baldwin refused to report for a physical examination after being drafted for military service in October, $1918 .^{50}$ Baldwin served a one-year prison term for his refusal; ${ }^{51}$ at his trial, Baldwin eloquently defended his pacifist views and his commitment to those ideals.

I know that it is pretty nigh hopeless in times of war and hysteria to get across to any substantial body of people, the view of an out and out heretic like myself. I know that as far as iny principles are concerned, they seem to be utterly impractical-mere moon-shine. They are not the views that work in the world today. I fully realize that. But I fully believe that they are the views which are going to guide in the future. ${ }^{52}$

Roger Baldwin and the National Civil Liberties Bureau were grounded in their defense of conscientious objectors and the right of pacifists to speak against World War I. Baldwin's own religious beliefs at the time convinced him that the conscientious objectors were riglit to oppose the war. In responding to a letter from a friend who had asked him whether he supported the war preparations of President Wilson, Baldwin wrote: "I am thoroughly with ... the pacifists now and all the time. I am unfortunately one of those who take the Sermon on the Mount pretty seriously, which does not square with the current conception of patriotism." ${ }^{.53}$ As Baldwin had said, his heretical and impractical views were not the ones that worked in the world at that time. But Baldwin's uncompromising belief that those "impractical" views would be the ideas to "guide in the future" sparked an organiza-

47. Id. at 74.

48. Id.

49. Id. at 92 .

50. See id. at 86.

51. See id. at 113-14.

52. Id. at 93.

53. Id. at 66 . 
tion's defense of the rights of those who refused to participate in war. Baldwin's willingness to stake out a substantive vision for a better society enabled the National Civil Liberties Bureau to understand what it was and the goals to which it aspired.

Today's public interest law also comes out of the struggle for equal rights for African-Americans, culminating in the civil rights efforts of the SCLC and the Reverend Martin Luther King, Jr. in the early 1960s. In 1909, the National Association for the Advanceinent of Colored People (NAACP) was established to combat the spread of racial brutality against blacks. ${ }^{54}$ In 1929, with $\$ 100,000$ froin the American Fund for Public Service, known commonly as the Garland Fund, the NAACP began a litigation campaign to remedy the legal, economic, and political woes of African-Americans. ${ }^{55}$ In 1939, the NAACP Legal Defense and Education Fund (NAACP/LDF) was established as a separate entity; working together with its parent organization, the NAACP/LDF won the landmark Brown v. Board of Education ${ }^{56}$ in $1954 . .^{57}$ The success of the NAACP/LDF and the changing political climate gave rise to perhaps the most important predecessor to modern public interest law, the Civil Rights Moveinent of the 1960s. ${ }^{58}$

During the turbulent 1960s, a committed group of civil rights proponents rallied behind Reverend King's "dream" for a new society-a vision of equality and freedom that liad long been demed to blacks in the Umited States. It was a dream firmly grounded in the Reverend King's theology and in the African-American churches that formed the SCLC's base. ${ }^{59}$

54. See Robert L. Rabin, Lawyers for Social Change: Perspectives on Public Interest Law, 28 STAN. L. REV. 207, 214-18 (1976).

55. See RICHARD KLUGER, Simple JUSTICE 132 (1976).

56. 347 U.S. 483 (1954).

57. See ARON, supra note 44, at 9. For a comprehensive study of the NAACP, the NAACP/LDF litigation strategy and the major figures who implemented it, see KLUGER, supra note 55.

58. See ARON, supra note 44, at 8. "The civil rights movement is, in many ways, the crucible in which modern public interest law was forged. The public interest law firms that have worked ... since the 1960s owe much of their organization, strategy, and inspiration to the National Association for the Advancement of Colored People Legal Defense and Education Fund ...." Id. Although the Civil Rights Movement might refer to a wide variety of organizations that worked in the 1960 s to achieve equal civil rights for African-Americans, this Note focuses on the non-violent civil disobedience acts and the legislative and judicial efforts of the SCLC and the followers of the Reverend King.

59. See generally RICHARD LISCHER, THE PREACHER KING: MARTIN LUTHER KING, JR. AND THE WORD THAT MOVED AMERICA (1995). 
Historians may "freeze" the Civil Rights Movement and isolate individual rhetorical performances that appear to be turning points or significant moments, but it is the ceaseless activity of biblical interpretation and preaching carried out by King and his colleagues that sustained the Movement as a whole and invested it with transcendent ineaning. Under his leadership the quest for equality and justice becaine a Word-of-God movement. ${ }^{60}$

King exhorted his followers to love their enemies not on the basis of umiversal moral laws or humanity's inherent goodness "but on the basis of the revealed nature of God." "Liberalism honored such Christian values as love and personality for their alleged conformity to the laws of the umiverse;" the Civil Rights Movement, in contrast, grew out of the theology of the African-American church, which "found its version of the unity of truth ... not in universal principles or propositions but in the entirety of its life as the people of God." "62

Reverend King's "drean" of a society without racial discrimination inspired activists in the Civil Rights Movement to work towards its realization. Because Reverend King and African-American churches filled the Movement with a theological vision of a just society, those activists were given a clear sense of purpose and identity. ${ }^{63}$ Some attempt to claim that the Civil Rights Movement is "central to the ethos of public interest law," that the Civil Rights Movernent's sense of purpose and identity is now missing from public interest law.

60. Id. at 219-20 (emphasis omitted).

61. Id. at 231.

62. Id. at 56 .

63. In Political Liberalism, Rawls admits that the theological grounding of Martin Luther King, Jr. and the Civil Rights Movement may be problematic for his articulation of procedural justice and the language of public reason. In a section entitled, "The Limits of Public Reason," Rawls argues that King's movement, whether King realized it or not, was not inconsistent with the use of the language of public reason. See RAwLs, supra note 18, at 247-52. Rawls notes in his discussion of the issue, however, that "I have not begun to cover the complexities of this question." Id. at 247 n.36.

64. BALANCING THE SCALES, supra note 44, at 40; see also ARON, supra note 44, at 10-11 (noting the ferment and change of the 1960s and 1970s which inspired further efforts to achieve social justice). 


\section{B. Public Interest Law Today}

Modern public interest law emerged froin legal advocacy groups such as the National Civil Liberties Bureau, the ACLU, the NAACP/LDF, and the Civil Rights Movement. ${ }^{65}$ At first, the public interest law moveinent consisted of new organizations that built upon their predecessors' successes in poverty and civil rights/civil liberties issues. "In the early 1970 s . . . the term "public interest law' applied to a self-contained, easily definable, and relatively homogeneous set of organizations." mid-1970s, lowever, when public interest law expanded drainatically. New groups were formed in an ever-increasing variety of substantive areas. The Ford Foundation, responsible for funding several of the new organizations through grants, ${ }^{67}$ published a report of its public interest law activities in $1976 .^{68}$ The report contained information on public interest legal work in ten different areas, though the Foundation pointed out that it represented "by no means all of what is being done in the public interest law field." ${ }^{69}$ The list is useful for its mention of the diverse practices newly-encoinpassed by public interest law: environmental protection, consumer protection, reform of government process (rulemaking), employment, responsiveness of mass inedia, health/mental liealth, women's rights, imternational issues, education, and electoral riglits. ${ }^{70}$ Since 1975 , the variety of substantive areas under the public interest law umbrella has grown even larger to include children's rights, juvenile rights, rights of gay, lesbian, and bisexual persons, indigent criminal defense, and civil and criminal government prosecution. ${ }^{71}$ Today, the variety of substantive practices

65. See Charles Halpern, The Public Interest Law Movement in the United States, in INNOVATIONS IN THE LEGAL SERVICES 101, 102 (Erhard Blankenburg ed., 1980). In the foreword to a book explaining the Ford Foundation's involvement in public interest law, Justice Thurgood Marshall wrote: "Today's public interest lawyers have built upon the earlier successes of civil rights, civil liberties and legal aid lawyers, but have moved into new areas." Ford Foundation, PUBlic INTEREST LAW: Five YeARS LATER 6 (1976).

66. ARON, supra note 44, at 3. 11.

67. See BALANCING the SCAles, supra note 44, at 40-44; ARON, supra note 44 , at

68. See FORD FOUNDATION, supra note 65.

69. See id. at 17.

70. See id. at 17-27.

71. See ARON, supra note 44, at $153-56$ (listing public interest organizations surveyed by the Alliance for Justice, a policy-oriented public interest law organization). 
which comprise public interest law can be seen in any law school's Public Interest Law Society's activities. ${ }^{72}$

Because of the increasing variety of organizations that claim its status, ${ }^{73}$ public interest law lias defined itself so as not to exclude organizations based on substantive legal programs. The diversity of substantive claims made by today's public interest law organizations and the tensions that result from the march of such a diverse group under one banner lias generally required that public interest law define itself in procedural, representation-based terms. ${ }^{74}$ Thus, Nan Aron, of the Alliance for Justice, ${ }^{75}$ describes the sine qua non of public interest law as "provid[ing] underrepresented groups witl access to the legal system." 76 Modern public interest law is repeatedly justified this way-in terms of procedure, ratler than in terms of a substantive vision:

The primary appeal of the public interest movement [is] stated in lawyerly terms, asserting that the public interest law firms [can] assure groups with a legitimate interest in an issue of an oppor-

72. In 1995, the Public Interest Law Society at Duke Law School conducted an informal written survey of the students in the class of 1997 regarding their interest in public interest law. Students were asked to identify from a list the fields in public interest law that were of interest to them. The two fields that generated the most response were Civil Rights and Criminal Law. The following fields of public interest law received at least five votes: Human Rights, Environmental Defense, Child Advocacy, Women's Rights, Labor, Consumer, Imunigration, Mental Health, AIDS, General Poverty Law, and Death Penalty. The public interest law fields of International Development, Health Care, and Technology/Conımunications each received one write-in vote. Animal Rights received no votes froin the survey list. Duke University School of Law, Public Interest Law Society, Survey of the Class of 1997 (Oct. 2, 1995) (on file with the Duke Law Journal).

73. For purposes of this Note, "public interest law status" is meant in the general sense that organizations use the language of the public interest to distinguisl their particular practice from private commercial work, and not necessarily the technical legal status given to public interest law firms under $\$ 501$ (c)(3) of the Internal Revenue Code.

74. Of course, generalizations about an area as diverse as public interest law cannot be absolutely accurate. The following accounts of public interest rhetoric do, however, give a sense of much of the public interest literature.

75. The Alliance for Justice is comprised of the leading policy-oriented public interest law organizations in the country. The Board of Directors represents 29 public interest law organizations whose diversity is indicative of public interest law's desire to embrace a wide spectrum of substantive practices. Membership includes the Children's Defense Fund, Natural Resources Defense Council, Center for Law in the Public Interest, NOW Legal Defense and Education Fund, Mexican American Legal Defense and Educational Fund, Native American Rights Fund, Center for Science im the Public Interest, National Women's Law Center, Mental Health Law Project, and the National Education Association. See ARON, supra note 44, at 134-35.

76. ARON, supra note 44 , at 4 . 
tunity to "have their day in court." The appeal [is] made in value-neutral terms, that is, in terms of enhancing the effectiveness of the legal process rather than asserting substantive values. $^{7}$

In this way, the language of modern public interest law has becoine the language of procedural justice as articulated by Rawls. Presumably, the "public interest" is something to which everyone in a pluralistic society can reasonably agree. This is an application of Rawls' theory of the "overlapping consensus."78 Because this overlapping consensus cannot rely on any compreliensive rehigious, philosophical, or moral doctrines, modern public interest law does not permit religious, philosophical, or moral ideas to define what it is or does. Public interest law's insistence on a procedural and value-neutral identity-that of merely assuring representationembodies the Rawlsian notion of the priority of the right over the good.

This was not the definition of justice for the National Civil Liberties Bureau or the Civil Rights Movement. Tle Reverend King, for instance,

routinely cited the Bible as the authority for his social activities, and cast the Civil Rights Movement in the light of biblical events and cliaracters.... Even when no text was cited and the deity was not mentioned, the audiences to [his] speeches considered themselves no less a congregation. King's self-proclaimed mission to 'redeem the soul of America' cannot be understood apart from his self-designated identity as a preacher of the gospel. ${ }^{79}$

The Reverend King's inovement represented a particular commumty with a particular substantive vision of the good whose cause was articulated as a moral and religious imperative. Modern public interest laws faces an identity crisis as it seeks to reconcile the substantive visions of its predecessor organizations with the extirpation of visionary language froin its modern "justice as procedure" rlietoric.

One public interest commentator attempts to solve this crisis of identity by recasting the substantive agendas of predecessor organizations in procedural justice terms. "Both [the NAACP and

77. Halpern, supra note 65 , at 103 (emphasis added).

78. See supra text accompanying notes 28-30.

79. LISCHER, supra note 59 , at 4 . 
the ACLU] used the legal process to clarify and protect the rights of minorities-blacks and persons deprived of civil liberties-who would not otherwise have had adequate representation in the legal process." ${ }^{80}$ This assertion-that African-Americans and other politically unpopular groups would have gone without representation but for the NAACP and the ACLU-is a crucial one. In modern public interest law rletoric, it is essential that these groups otherwise go without representation, because without this need the ACLU and NAACP might be seen as endorsing the substantive views of their clients or, worse, claiming that their clients' victories would enhance the common good. Modern public interest law, unlike its predecessors, demies the substantive good to be achieved by the victory of its clients.

It is interesting to note that the Civil Rights Moveinent and other predecessor inovements were never labeled as simply coinponents of a greater public interest law effort. ${ }^{81}$ The Civil Rights Moveinent was never known as a "public interest" inovement precisely because its work was driven by a substantive vision for a better society; it never claimed to be a public interest inovement because it was all too aware that not everyone shared Reverend King's "dream" for a better society. Activists in the Civil Rights Moveinent knew that Governor George Wallace, Bull Connor, and inany others were fundamentally opposed to the new substantive vision of an integrated society that the Civil Riglts Movennent offered to the nation. But it was precisely because the Civil Rights Movernent was willing, in the words of Roger Baldwin, to make a "lieretical" claim about its vision for society that the Movement inspired and affected the hives of so many people in the 1960s.

The National Civil Liberties Bureau and Reverend King's substantive visions for a better society provided goals and identities. The lack of such vision leaves today's public interest law defined in representation-inaximizing and procedural terms, without any compelling, substantive goals or sense of identity.

\section{PRo-Free ENTERPRISE PUblic INTEREST LAW FIRMS}

If public interest law can be adequately and accurately defined in procedural terms, then the substantive claims of different public

80. Halpern, supra note 65 , at 102 (emphasis added).

81. See supra note 44. 
interest organizations should pose no problems for public interest law's sense of identity. So long as an organization serves the "public reason" of providing representation to the unrepresented, underlying substantive claims should be of no significance. But the rise of pro-free enterprise public interest firms in the late 1970s and the response of older, traditional public interest law organizations created animated bickering between groups. The rift revealed that different groups had very different conceptions of the "public interest." This rift between traditional public interest law organizations and the newer pro-free enterprise public interest law groups demonstrates that procedural conceptions of justice fail to adequately define public interest law.

In the late 1970s, following closely on the heels of traditional public interest law organizations' successes in poverty and civil rights law, several new groups, with a radically different substantive vision of what was in the interest of the public, were organized. ${ }^{82}$ According to the new public interest lawyers, the old guard had been "[w] $[$ eighted down by its special interest group entangleinents" 83 and entertained "tragic consequences of expedient, ad hoc case selection covered with a public interest veneer." ${ }^{34}$ In place of an "environmental and welfare rights" public interest, the pro-free enterprise moveinent proposed a radically different agenda, one "devoted to individual rights and economic liberty." ${ }^{35}$ The resulting tension between these different substantive visions for public interest law is illustrated by the number of cases where traditional public interest firms and the newer pro-free enterprise organizations squared off against one another as amici curiae. ${ }^{86}$

82. These groups may broadly be referred to as the "pro-free enterprise public interest movement" and includes organizations such as the Pacific Legal Foundation, Washington Legal Foundation, Center for Individual Rights, and the Landmark Legal Foundation. See William H. Mellor III \& Clint Bolick, The Quest For Justice: Natural RIGHTS AND THE FUTURE OF PUBLIC INTEREST LAW 4 (Heritage Found. Lectures No. $342,1991)$.

83. Id. at 1.

84. Id. at 3.

85. Id.

86. See, e.g., Pennell v. City of San Jose, 485 U.S. 1 (1988) (Washington Legal Foundation urging reversal and ACLU, Asian Law Alliance, National Housing Law Project urging affirmance); Wygant v. Jackson Bd. of Educ., 476 U.S. 267 (1986) (Mid-America Legal Foundation, Pacific Legal Foundation urging reversal and Affirmative Action Coordinating Center, Greater Boston Civil Rights Coalition, Lawyers' Committee for Civil Rights Under Law, Mexican American Legal Defense and Educational Fund, Michigan Civil Rights Commission, NAACP Legal Defense and Educational Fund urging affir- 
On behalf of the traditional public interest community, Nan Aron has described the pro-free enterprise law firms' place in the public interest law community: "public interest law can no longer be thouglit of as a monolithic movement dedicated to any one political agenda.... While focusing almost exclusively on the needs and concerns of the business community, these groups nonetheless operate under the mantle of a public interest law firm ...." Thi This acceptance of the pro-free enterprise agenda within public interest law, though strained, seems appropriate given the definition of public interest law as a non-substantive, representation-maximizing field.

However, Aron inakes it clear that the substantive agenda of this new public interest movement does matter for traditional public interest groups like the Alliance for Justice. ${ }^{88}$ Aron views the 1980s as a resounding defeat for public interest law, a decade in whicl victories won by public interest lawyers during the 1970s were undone by a hostile Reagan Administration. That Administration's agenda, lowever, was the same one espoused by profree enterprise public interest law organizations sucl as the Pacific Legal Foundation. ${ }^{89}$ Aron, in fact, notes that several leaders of pro-free enterprise public interest law organizations occupied high positions of authority within the Reagan Administration, including James Watt, Director of the Mountain States Legal Foundation

mance); New Jersey v. T.L.O., 469 U.S. 325 (1985) (Washington Legal Foundation urging reversal and ACLU, Legal Aid Society of the City of New York urging affirmance); Chappell v. Wallace, 462 U.S. 296 (1983) (Washington Legal Foundation urging reversal and ACLU, Lawyers' Committee for Civil Rights Under Law, NAACP Legal Defense and Educational Fund, Inc. urging affirmance).

87. ARON, supra note 44 , at 4 . Aron also includes several conservative public interest organizations in an appendix to the book, entitled, "Directory of Public Interest Law Centers." Id. at 137-46.

88. Although Aron and the Alliance for Justice are used in this Part to represent the response of traditional public interest groups to the rise of pro-free enterprise public interest law, they are by no means the only groups to articulate such views. See also James W. Singer, The Challenge from the Right, in EQUAL JUSTICE FOUNDATION, TAKING IDEAS SERIOUSLY 88, 89 (Robert L. Ellis ed., 1981) (discussing response of other traditional public interest groups); Oliver A. Houck, With Charity for All, 93 YALE L.J. 1415, 1454-545 (1984) (examining the activities of business-sponsored public interest law firms against background of traditional public interest law concepts).

89. Aron makes no attempt to conceal her scom for pro-free enterprise public interest law when she writes that the "Pacific Legal Foundation [a conservative public interest group] is a public interest law firm in the same way catsup [was] a vegetable under Reagan's ... school lunch guidelines." ARON, supra note 44, at 63 (quoting Houck, supra note 88 , at 1544 ). 
and then Secretary of the Interior, and Edwin Meese, one of the founders of the Pacific Legal Foundation and Attorney General in the Reagan Administration..$^{90}$

Aron reacts to the rise of the pro-free enterprise public interest law movement as if these organizations, although working under the auspices of the "public interest," violated what it means to work in the "public interest." Aron is right-as the history of the ACLU and the Civil Rights Movement demonstrates, there was a time when "public interest law" was concerned not merely with representing the underrepresented, but with advocating the substantive interests of the disadvantaged, marginalized, and oppressed. The pro-free enterprise "public interest" groups can certainly claim to be representing underrepresented interests, but they cannot credibly clain to be doing the same kind of substantive work that the ACLU, the Civil Rights Movement, and other traditional public interest groups have done for so long.

Modern public interest law's unwillingness to bring pro-free enterprise public interest law into the fold demonstrates the inadequacy of eliminating a substantive conception of justice from public interest law. Traditional public interest lawyers want to deny pro-free enterprise lawyers like James Watt the right to call themselves public interest lawyers. The problem is that, given a valueneutral definition of public interest law, traditional public imterest lawyers cannot resort to substantive criteria in order to define what is or is not in the public interest. A Rawlsian, procedurebased conception of justice does not provide the language necessary to distinguish organizations based on their substantive articulation of the good.

Some traditional public interest law groups respond to profree enterprise public interest law organizations by claiming not to speak for the true substantive public interest, but only the true procedural public interest. 91 "The older groups maintain that they have never pretended to speak for the public interest. They say it's what they do that's in the public interest: enabling previously unrepresented groups to be represented in the public policy process in the same maimer as the established interests." gument is unconvincing, lowever, because pro-free enterprise

90. See id. at 76 .

91. See Singer, supra note 88 , at 89 .

92. Id. 
groups can respond with an identical argument-that the ideologies of "individual rights" and "economic liberty" go largely unrepresented in today's legal systein. ${ }^{93}$ They can claim they are also working in the public interest by providing representation to the underrepresented interests of corporate and business defendants against the "established" interests of environmental and welfare rights plaintiffs. But this claim, no matter low tenuous, is not half so ridiculous as the claim that the pro-free enterprise groups might represent the substantive interests of the disadvantaged, marginalized, and oppressed. If public interest law were to define itself in such substantive terms, the pro-free enterprise groups would be forced to make this unsupported claim or lose the mantle of the public interest. Unless public interest law defines itself in terms that recognize this substantive distinction instead of liberal, procedural platitudes about mere representation, it literally will forget what it was that it wanted to do in the first place.

\section{AN UNCONTROVERSIAL GLOSS FOR SUBSTANTIVE VALUES}

Though the rhetoric of public interest law centers on a procedural vision of justice, this is not in accord with the actual practice of many public interest lawyers. ${ }^{94}$ Two possible interpretations of the phrase "representing the unrepresented" exist. ${ }^{95}$ The first interpretation is the strictly procedural definition for public interest law in which justice results from the exercise of proper procedure. This definition is consistent with Rawls' theory of "justice as fairness." 96 The second interpretation, however, holds that the procedural definition is "merely an uncontroversial gloss for more substantive values." ${ }^{\text {"97 }}$ This latter interpretation is most applicable to modern public interest law.

The rhetoric of procedural justice hides the fact that many practitioners of public interest law do beheve in a substantive good towards which they are working. ${ }^{98}$ One public interest commenta-

93. See supra text accompanying note 85 .

94. For the argument that the practice of a profession cannot be controlled by the theories used to describe that practice, see Stanley Fish, Dennis Martinez and the Uses of Theory, 96 YALE L.J. 1773, 1777-79 (1987).

95. Heineman, supra note 13 , at 184 .

96. RAWLs, supra note 19 , at $3-53$.

97. Heineman, supra note 13 , at 184 .

98. The argument in this section reflects the more general philosophical critique of Rawls that justice cannot be divorced from substantive accounts of "the good life." See 
tor points out what would seem to be obvious-that public interest lawyers believe both that their clients should win and that their clients' victories would be good for society. "The purpose of providing legal resources for formerly unrepresented consumers or enviroumentalists is to secure decent products or to proinote clean air. Blacks or Puerto Ricans need lawyers because racial equality is an unalloyed good."99 Most public interest lawyers do believe that their claims on behalf of the unrepresented and underrepresented are contributing to a greater social good. This leads to a tension between the substantive vision of lawyers engaged in the practice of public interest law and the rhetoric of procedural justice that pervades modern justifications for public interest law. To the extent that pubhic interest lawyers incorporate notions of procedural justice into their practice, this tension helps account for public interest law's current crisis of identity.

A comprehensive report on public interest law acknowledges that public interest lawyers typically do not regard theinselves as such. Public interest lawyers are more likely to identify thenselves by the substantive issues they work with and the people they represent.

The lawyers whose activities are described in this Report are likely to identify themselves not as 'public interest lawyers,' but in terms of their specific areas of focus: consumer protection, poverty, civil rights, the environment. Within those areas, many of them ... may well believe that their clients' positions on the issues represent what is in the public interest. ${ }^{100}$

Another public interest law commentator observed that "to label a lawyer a 'public interest lawyer' because he is 'naking pluralism operative' suggests that his personal commitment is to the process ... . whereas in fact he inay be, and generally is, committed to realizing the substantive interests he represents."101

Marc Feldinan, a former Legal Services supervising attorney, has written that the rhetoric of a procedural conception of justice

Sandel, supra note 23 , at 1766 . Though that argument is beyond the scope of this Note, for an articulation of this philosophical response to Rawls, see MACINTYRE, supra note 25; ALASDAIR MACINTYRE, WHOSE JUSTICE? WHICH RATIONALITY? (1988); SANDEL, supra note 15; Sandel, supra note 23.

99. Heineman, supra note 13 , at 184 (emphasis added).

100. BALANCING THE SCALES, supra note 44, at 209.

101. Comment, supra note 17, at 1070 n.3 (emphasis added). 
may nevertheless weaken the professional identities of Legal Services attorneys and their ability to adequately serve their clients. In Political Lessons: Legal Services for the Poor, he identifies the way in which the Rawlsian conception of procedural justice contributes to an identity crisis in public interest law:

What is revealing ... is the absence of responsibility and accountability by lawyers for the client goals they pursue and the consequences that result from their actions. Despite larger claims about the connections between lawyer's role and "truth," "autonomy," "rights," and "curbing excesses of the state," it is not the lawyer's job to pursue the truth, but to pursue the process from which the truth einerges.... [A]n attorney's obligations are limited to the means of client participation and never to the substantive ends that result. ${ }^{102}$

In process-defined justice, the attorney-client relationship is divorced from a conception of the substantive good to be achieved through the representation. The attorney-chent relationship is reduced to representation for its own sake. In Feldman's view, this procedural definition of the attorney-chent relationship has contributed to the inability of many Legal Services attorneys to serve their clients well. "The lawyer-client relationship is explained and justified because of its potential for personal fulfillment. No longer is the relationship an opportunity for service, a moral commitment, or a political alliance; it is now a 'good in itself." "103 Feldman's critique of value-neutral conceptions of the good in the relationship between the Legal Services attorney and her chent mirrors the crisis of public interest law as a whole.

According to Feldinan, not only is procedure-based justice contributing to a crisis of identity, but in the practical realm, it may not even be successful at accomplishing its goal of adequate representation.

For the poor, the byword for this participation in the legal system is "access." ... The operating presumption is that if some-

102. Marc Feldman, Political Lessons: Legal Services for the Poor, 83 GEO. L.J. 1529, 1596 (1995) (emphasis added) (citing Gerald J. Postema, Moral Responsibility in Professional Ethics, 55 N.Y.U. L. REV. 63, 73 (1980)).

103. Id. at 1608 (emphasis added); see also William H. Simon, Homo Psychologicus: Notes On a New Legal Formalism, 32 STAN. L. REV. 487, 536 n.162 (1980) (finding that psychologists encourage law students to understand loyalty to the client as a form of "self-actualization" rather than moral commitment). 
one can get to court and make her case known in intelligible fashion, then she will prevail in approximate relation to the merits of her position. This presumption is rarely subjected to scrutiny; there is hittle or no inquiry about substantive results .... When we do ask these questions we learn that the poor do not win even an appreciable fraction of their cases. This result is not merely a failure of access or participation. Instead, it reflects a fundamental and antagonistic disposition towards the interests of the poor. ${ }^{104}$

To say that the emphasis on procedural justice is simply an uncontroversial gloss for substantive behefs invites opposition. "Given the political controversy that is certam to arise when substantive values are aggressively asserted as being in the public interest, the procedural justification for public interest law has always been the more conservative one: It fits inore easily into the norms of our political and legal culture."105 Recall that Rawls' theory of procedural justice is a mechanism intended to reduce conflict in a society where diversity of moral, philosophical, and religious thought is a permanent condition. ${ }^{106}$ Similarly, public interest law has relied on procedural interpretations of justice in order to reduce conflict between competing organizations and their different conceptions of the good. But if Marc Feldman's observations are correct, then the rhetorical use of procedural justice to define public interest law, even if merely an uncontroversial gloss, inay liave a negative effect on public interest lawyers' view of their role as advocates for the poor and inarginalized.

\section{CONCLUSION}

This Note has argued that a procedural understanding of justice cannot adequately or accurately provide a foundation for the work of today's public interest law attorney and has suggested that the lack of a substantive vision has created public interest law's identity crisis. Professor Thoinas Shaffer writes that, in order to speak about ethics, "we lave to know, or be able to find out, where we want our lives to be lieaded."107 Liberalism's language

104. Feldman, supra note 102 , at 1598 (footnote omitted).

105. Heineman, supra note 13 , at 185.

106. See supra notes $24-25$ and accompanying text.

107. THOMAS L. SHAFFER \& MARY M. SHAFFER, AMERICAN LAWYERS AND THEIR COMMUNITIES: ETHICS IN THE LEgAL PROFESSION 42 (1991). 
of procedure eliminates the substantive vocabulary needed for public interest lawyers to articulate a conception of where society should be heading. The liberal model, though it puts up an enormous umbrella under which a great variety of groups can take refuge, ultimately spreads itself so thin that it provides no meaning for anyone.

Professor Michael Sandel has written that the hiberal language of "public reason" generates certain political costs. "These costs are becoming mcreasingly apparent im the politics of those countries, notably the United States, whose public discourse most closely approximates the ideal of public reason advanced by political liberalism." 108 Sandel argues that

American political discourse in recent decades has coine to reflect the liberal resolve that government be neutral on inoral and religious questions, that fundamental questions of public policy be debated and decided without reference to any particular conception of the good. But democratic politics cannot long abide a public life as abstract and decorous, as detaclied froin moral purposes, as Supreme Court opinions are supposed to be. A politics that brackets morality and rehigion too completely soon generates its own disenchantment. ${ }^{109}$

"Disenchantment" is an apt description for the crisis in which public interest law currently finds itself. Without the ability to use the substantive language of morality or faith to explain why it does what it does, public interest law can only aspire to serve a broad, attenuated sort of "public interest." Public interest lawyers should stop working to hold up such a "public interest" and realize that, $\mathrm{m}$ the words of Roger Baldwin, their visions for society "are not the views that work in the world today." Stepping out from under the cloak of substantive neutrality will be controversial and difficult, but lawyers for the poor and marginalized who do so with a clear sense of identity and purpose can hope that their dreams of a better society will one day be realized.

108. Sandel, supra note 23 , at 1793.

109. Id. at 1793-94 (footnote omitted).

110. See LAMSON, supra note 45 , at 93. 
